in the University to rank along with the other Faculties of Art, Science, and Medicine, and to live alongside them in the closest intimacy. To do this effectively required judgment, imagination, and particularly courage and the faculty of dealing wisely with men and affairs. Prof. Smithells had written and spoken on this subject but always impersonally. On this occasion it was only proper that prominence should be given to the personal aspect, and the dominating part played by Prof. Smithells in this work fully and freely acknowledged.

Further support came from Prof. B. M. Connal, speaking as an old Arts colleague, and from Mr. J. Ferguson Bell, the president of the Institution of Gas Engineers, who, speaking for the gas industry, acknowledged the great indebtedness which they felt to science in application to their industry and particularly to the work of Prof. Smithells and the University of Leeds.

The portrait was received by the vice-chancellor on behalf of the University.

Prof. Smithells then described how his scientific work on flames had brought him into contact with the gas industry and its problems, and acknowledged, in impressive terms, its generosity to the University and the honour now paid to him. Referring to his colleagues, past and present, he paid a tribute to the founders of the old Yorkshire College and the remarkable group of men of science-Green, Rucker, Thorpe, and Miall - who in the early years so successfully disseminated the right spirit in the young institution, which ensured its initial success and later progress. To the late Prof. L. C. Miall he expressed a special personal tribute and the belief that no man did more for the spirit of the College and University. Speaking of the scholarship to be founded with the funds subscribed, he had wondered for a moment whether unity of knowledge might not receive appropriate illustration by devoting it to some literary end, but the idea was no doubt somewhat fantastic in this connexion. After all, he believed in science and shared the conviction expressed by a great man of letters, Mr. Galsworthy, that the future of the race was in the hands of science. It was right and proper, therefore, that this scholarship should be devoted to its advancement. In complimenting Dr. Baillie on his appointment as vice-chancellor, he assured him of a generous welcome, and expressed a firm faith in the modern university.

It was announced that the Smithells Fund would allow, after payment of the portrait and incidental expenses, of the establishing of a scholarship bearing the name of Prof. Smithells, within the University, of approximately rool. per annum.

\section{The British Dirigible Programme.}

THE decision to take up again the development of dirigibles in Great Britain has probably been influenced by the example of the United States.

The following table gives a basis of broad comparison with German craft:

\begin{tabular}{|c|c|c|c|c|c|c|c|}
\hline Name. & Length. & Diam. & Volume. & $\begin{array}{c}\text { Displace- } \\
\text { ment. }\end{array}$ & Power. & Speed. & $\begin{array}{l}\text { Length/ } \\
\text { Diam. }\end{array}$ \\
\hline $\begin{array}{l}\text { R ror } \\
\text { "Burney", } \\
\text { ZR } 3 . \\
\text { L } 59 . \\
\text { Bodensee }\end{array}$ & $\begin{array}{l}\mathrm{m} . \\
220 \\
212 \\
203 \\
226.5 \\
\mathrm{I} 2 \mathrm{I}\end{array}$ & $\begin{array}{l}\text { m. } \\
39 \cdot 9 \\
40 \cdot 5 \\
28 \\
23 \cdot 9 \\
18 \cdot 7\end{array}$ & $\begin{array}{r}\text { cub. m. } \\
\text { I } 43,000 \\
\text { r } 43,000 \\
70,000 \\
68,500 \\
20,000\end{array}$ & $\begin{array}{c}\text { tons. } \\
\text { I65 } \\
165 \\
81 \\
79 \\
23\end{array}$ & $\begin{array}{c}\text { k.w. } \\
7 \times 430 \\
7 \times 430 \\
5 \times 300 \\
5 \times 180 \\
4 \times 180\end{array}$ & $\begin{array}{l}\mathrm{km} / \mathrm{hr} . \\
\text { I } 5 \text { est. } \\
\text { I } 5 \text { est. } \\
\text { I } 40 \text { max. } \\
\text { I } 3 \text { I max. } \\
\text { I } 35 \text { max. }\end{array}$ & $\begin{array}{l}5 \cdot 5 \\
5 \cdot 25 \\
7 \cdot 25 \\
9 \cdot 5 \\
6 \cdot 45\end{array}$ \\
\hline
\end{tabular}

German practice shows much greater ratios of length/diameter; in the case of the L 59, this was perhaps due to the greater ease with which existing airsheds can be increased in length than in height and width; but the Bodensee, a successful post-War commercial craft, and the $\mathrm{ZR} 3$, the latest example of German design, were free from this restriction.

In passing from the $Z R_{3}$ to the $R$ Ior and the "Burney" the volume and power are both doubled, so that with similar shapes there should be an increase in speed of about $2^{1 / 9}=\mathrm{I} \cdot 08$, or from $\mathrm{I}_{4} \mathrm{O}$ $\mathrm{km}$. $/ \mathrm{hr}$. to $\mathrm{I}_{5} \mathrm{I} \mathrm{km}$. $/ \mathrm{hr}$., as compared with II $5 \mathrm{~km}$. $/ \mathrm{hr}$. which is a heavy margin in estimating. The shapes are, however, very different.

Tests at the National Physical Laboratory on relatively minute models in the wind-tunnel indicate a "best" ratio of length/diam. between 4.5 and 6 . Presumably the British designers are not relying solely on a very doubtful aerodynamical similarity, and it would be interesting to know the full size data on which they are departing so boldly from German practice.

The United States naturally hold for themselves the only supplies of helium, and the best method open to other nations for reducing fire risks is by installing heavy oil engines as is specified for the new British craft. The specification of "stainless" steel for the metal framework indicates a surprising advance in the design of members to resist local buckling in the very thin webs and flanges as compared with lighter and bulkier duralumin.

In a previous note (Nature, October II, p. 548), the useful life of a dirigible was estimated from German records as less than two serious voyages per month for eighteen months, excluding fire and war risks. It remains for time to show how far the $\mathrm{ZR} 3$ in American hands, and the new British craft in British hands, will compete with this standard of performance set up by the Germans after more than twenty years' experience.

No doubt it is difficult for the authorities to neglect completely a potential weapon, even though the aeroplane has proved an almost perfect antidote. From this point of view alone, their decision is entirely defensible. The long delay in coming to it may well be explained by the formidable nature of the problem taken as a whole.

\section{University and Educational Intelligence.}

CAMBRIDGE.-The time having lapsed during which the University can suspend the Jacksonian professorship of natural philosophy, and no new scheme for it having been adopted by the University, the Vice-Chancellor has declared that the professorship is vacant. An election will take place on January 5 next.

Mr. F. Balfour Browne, Gonville and Caius College, has been appointed University lecturer in zoology.

LONDON.-The title of professor of anatomy in the University has been conferred on Mrs. M. F. Lucas Keene, in respect of her post as head of the Department of Anatomy at the London School of Medicine for Women. Prof. Lucas Keene was appointed lecturer in anatomy and embryology, with charge of the department, at the London School of Medicine for Women in 1919, and the title of reader in anatomy in the University was conferred on her in respect of this post in I92 I.

A course of free public lectures on "The Anatomy and Physiology of the Sympathetic Innervation of the Striated Muscle " will be given at University College, at five o'clock on December 8, Io, and I2, by Prof. J. I. Hunter, of the University of Sydney. No tickets will be required.

Applications are invited for the chair of pathology at the London (Royal Free Hospital) School of Medicine for Women. Twelve copies of each appli-

NO. 2875 , voL. I I 4$]$ 
cation should be received by, at latest, the first post of January 29 by the Academic Registrar, University of London, South Kensington, S.W.7.

Applications are invited by University College, Nottingham, for a lectureship in psychology. The person appointed will take charge of the psychological laboratory and be expected to assist in the teaching of philosophy. Forms of application (returnable not later than December ro) can be obtained from the registrar.

A FULL-TIME male teacher of chemistry is required at the Northern Polytechnic Institute, Holloway, N.7, with a knowledge of the application of chemistry to the building and rubber trades. Candidates must be university graduates, preferably with honours degrees. Application forms are obtainable from the Secretary of the Institute.

It is stated in the Chemiker Zeitung that two newly created professorships in the medical faculty of the University of Münster have been filled by the appoint ment of Dr. Heinrich Többen to the chair of forensic medicine, and of Dr. Hermann Freund, of Heidelberg, to the chair of pharmacology.

Prof. W. H. MoBerly, professor of philosophy in the University of Birmingham, has been appointed principal of University College of the South-West, Exeter, in succession to Principal Hetherington, who is becoming professor of philosophy in the University of Glasgow.

The Leeds University Calendar for I924-25 refers to the jubilee celebrations which will take place during the week December I 5-20. Fifty years have elapsed since Yorkshire College was established as a College of Science, and forty since it was united with the Leeds School of Medicine, founded in I83I. The College formed part of the Victoria University, Manchester, from 1887 to I904, when the University of Leeds was established by Royal Charter. The new Calendar, unlike previous issues, gives no particulars of the staff.

THE Educational Record, published quarterly by the American Council on Education, gives in its July number an interesting series of reports on the various activities of the Council and its committees during the past year. Like the Standing Committee of ViceChancellors in Great Britain, it was formed under the stress of war-time conditions, and has steadily grown during the past six years in importance. It is now the most influential voluntary body for the promotion of the interests of education in the United States. Some idea of the scope of its work can be gathered from the following list of subjects dealt with by its several committees: educational finance, federal legislation, college and university personnel, foreign language teaching, Franco-American exchange, international educational relations, foreign travel and study, college standards. The Director classifies the Council's activities under five main headingsstandards, personnel, national relations, international relations, and research. It is his special care to ensure that work done under each of these heads is guided so as to contribute most fully to the advancement of the work in progress under the other heads. One of the most important of the Council's enterprises is the "Division of College and University Personnel " created two years ago for compiling a perpetual register of college teachers, their academic careers and qualifications, for the whole of the United States.

No. 2875 , voL. I I 4$]$
THE annual meeting of the Geographical Association will be held on January I-3 at the London School of Economics, and arrangements have been made for members to travel to the meeting at reduced railway fares. Prof. J. L. Myres will deliver his presidential address on "A Geographical View of the Historical Method in Ethnology" on January 2, and he will also broadcast a message on "Wayside Geography" on the previous evening. Included among the numerous illustrated lectures which will be given is one by Mr. R. U. Sayce, of the Department of Geography, Natal University College, on aspects of the human geography of Natal. On January $\mathrm{I}$, a discussion, to which all university teachers of geography are invited, will be opened by Prof. J. I. Myres on "Departmental Research Programmes," while on the next day there will be a symposium on the life of fiord people, at which Dr. A. Sommerfelt (Kristiania), Mr. Henry Balfour (Oxford), Mr. C. E. P. Brooks (Meteorological Office), and Mr. C. B. Fawcett (Leeds) will speak. January 3 is to be devoted to special sessions on the teaching of geography. The first discussion, on school geography, will be opened by Mr. S. W. Rider (Gowerton County School) and Capt. T. K. Mortimer Booth (Christ's Hospital). At midday, four simultaneous discussions will be held : on the beginnings of geography, the teaching of climate, home geography, and school geography clubs and journeys. The afternoon will be devoted to excursions to various parts of London, including a party under the leadership of Mrs. Ormsby to beat the bounds of the City of London. On the first two days of the meeting a publishers' exhibition of books and maps will be open. Further particulars of the meeting can be obtained from the secretary of the Association, Ix Marine Terrace, Aberystwyth.

"Continuity" was the text of a speech by the president of the Board of Education at the annual dinner of the London Teachers' Association on November 29. He hoped that in the coming year careful surveys of the field of education would be made by local authorities with the view of framing comprehensive schemes of development. Such a scheme has just been drawn up by the West Riding Education Committee providing for new capital expenditure during the years I926 to 1932 on sites, buildings, and equipment, of $\mathrm{r}, 000,000 \mathrm{l}$. for elementary, $543,000 l$. for secondary, and $300,000 l$. for technical education, entailing maintenance charges of $270,000 l$. per annum. Among the improvements aimed at are : (I) the reduction in size of classes (at present 946 classes contain more than 50 and $\mathrm{I}_{332}$ from $4 \mathrm{I}$ to 50 children each); partly by means of (2) Central Schools in which adequate provision, impossible under present conditions, will be made for (3) instruction in handicraft and domestic subjects; (4) increasing the proportion of attendance at secondary schools from 9.5 to 15 per thousand of the population; (5) to provide for technical and other forms of further education 84 new schools and Io enlargements or replacements. Under the last-mentioned head are included not only technical schools in buildings provided for the purpose or used jointly as secondary or middle schools, but also technical classes with "facilities for practical work in Science, Manual Training, Cookery, History, Social Science, Pure Natural Science, Botany, Entomology, etc., that might suitably be incorporated in the buildings of a Central School or a Central Top for a group of elementary schools." The annual additional charge on the rates, assuming that the capital is to be borrowed, will, it is estimated, amount to $6 d$. in the pound on the basis of existing assessable values. 